\title{
Dimensions in Teaching Skills and Learning Skills
}

\section{Divya Deevi}

Research Scholar

Asst. Professor in English

VNR Vignana Jyothi Instititute of Engineering and Technology

Hyderabad, India

divya.kavi0@gmail.com

Kavi Bala Brahma Chary

Lecturer in English (Retired)

Hyderabad, India

kavibbc@gmail.com

\begin{abstract}
Teaching skills and learning skills existed even in the ancient times, though the terms were coined at a later stage. Dire necessity forced the ancient man to learn skills like hunting animals for food. As mankind was heading towards new civilisation, teaching skills found a place in society. Saints demonstrated skills in education as well as in warfare to princes. These teaching skills and learning skills have taken new dimensions to cater the needs of changing trends in all fields. Teachers exhibit skills like classroom management, use of black board and skill of explaining. Drastic changes have taken place in learning skills as well. Some people like craftsmen learn skills without formal education. But modern education demands organised classroom study. So, students have to acquire learning skills like concentration, punctuality and discipline. However the modern trends and necessities in education require constant developments in teaching skills and learning skills. The learning
\end{abstract}


process has no end. It starts from childhood and lasts till death. This paper deals with various aspects of teaching skills and learning skills which are inevitable in education.

Keywords- Teaching skills- Learning skills- New dimensions- Cater the needs of educationClassroom management- Skills of explaining- Constant development- Learning a continuous process.

Like any other professional- a doctor, a lawyer an engineer- a teacher must possess professional skill in his field. Otherwise, he cannot become popular or famous. In fact any professional who is unable to exhibit his skill may do injustice to his profession and sometimes may cause harm to the individuals. A doctor, who fails to show his skill, may put patient in trouble. A lawyer, who cannot argue skilfully, may cause a lot of grief and injustice to his client. In the same way, a teacher without professional skill cannot inspire students. But acquiring knowledge is quite different from possessing skill. One can gain knowledge by studying in classrooms, reading books outside and now-a-days accessing to the internet. However, one can get skill by birth. One can enhance one's skill through regular practice. A meritorious student may not become a skilled professional but an average student can become renownedin his profession because of his skill.

According to Morrison, "Teaching, in simple words,implies imparting of knowledge and skills by an expert teacher to a novice learner. Teaching implies an intimate contact between a more-mature (teacher) and less- mature(learner) personality which is designed to further the education of the latter(pupil)." As already mentioned, skill needs to be brushed up. A teacher with his behaviour, voice, looks and body language can attract students. First, he must create confidence among students that they can learn well from him. It happens only when the teacher prepares before- hand and gets a complete and thorough knowledge of the subject. He should present it skilfully so that students can grasp and understand it. Hough and Duncan say "Teaching is an activity- a unique, professional, rational and human activity in 
which one creatively and imaginatively uses himself and his knowledge to promotethe learning and welfare of others."'If a same topic is taught by different teachers, only a teacher who explains it with skill is remembered and respected by students. It does not mean that other teachers are not worthy. What they lack is skill and application of the subject.

Another skill to be practised by the teacher is closeness with students. It is very important because students must feel free to ask any doubt in the classroom. If a student is afraid of expressing his opinions confidently, it is the fault of the teacher, not of the students.

Use of external teaching material is a skill to be followed by the teachers. A teacher should judge the context and use relevant material. He can take the help of blackboard and piece of chalk or power point presentation. It depends on the subject and the age of students and their power of grasping. Sometimes teachers can ask students to make some objects by themselves. They can guide them in doing so if necessary. They must always observe whether the materials show any impact on their ability to receive the subject.

A teacher must hold the attention of the students. All students should show enthusiasm and interest to listen to him. Then only the teacher can convey his ideas on the subject clearly. Learning beyond the class subjectis one of the most essential skills of the teacher. It is rightly said that a teacher is an eternal student. So, a teacher must spend some time in library to refer to books and read newspapers regularly. The technology is bringing out drastic changes in all domains including education. Traditional class rooms are being replaced by e-classrooms even at lower standards. He must also make students know about current affairs.

Interacting with students is also an important skill. As far as possible a teacher must remember the names of all students in the class. A student feels happy and proud if he is called by name by the teacher while asking a question. He may not answer the question correctly, but he learns how to convey his opinion freely. If the answer to the question is 
discussed in a class the scope of the subject will be increased. Then with the help of the teacher, students come to a right conclusion about the topic. If necessary he can divide students into some groups and ask them to discuss a topic. Finally their opinions are collected and the merits and the demerits are explained. Thus he can encourage group discussion among students.

Classroom management is an integral part of teaching. A teacher must impose strict discipline among students. He must also explain the need of maintaining punctuality. But he must not act as a dictator. He can convince students that discipline and punctuality play a key role in their future. He should not be lenient but liberal. He can resort to punishment very rarely. An erring or naughty student must be punished in one way or the other.

The teacher must show his skills in using illustrations. In his explanation as per the need he must formulate simple, relevant and interesting examples. By doing so he can create curiosity in the students. Thus students get clarity of the subject.

Questioning is also a primary skill. Generally answering questions happens in examination. But a teacher should always, if possible, daily question students about the topic he has taught. The answers given by each student should be taken into consideration. If there are different opinions conveyed by the students, he must clarify beyond any doubtandall the students should come to a clear idea about the topic.

The other facet of teaching skill is learning skill. Learning is an internal activity and a key personal development skill. Regarding learning skill there is an apprehension that learning is the primary responsibility of the students. But that is not true .Learning should be practised by teachers as well.Teaching is as crucial as learning. A person who learns well teaches well.

"Learning is defined as a change in the behaviour of an organism. It is a process that results in the modification of the behaviour of an individual learner through some activity, act 
of training or experience"-(Pathak, R. P. 2012. Teaching skills, Delhi: Dorling Kindersley, (India) pvt. Ltd, Licensees of Pearson Education in South Asia. p.110.)

Learning process starts from childhood. Children learn words from their parents. They also learn making toys with clay,paper and other materials. The learning competence varies from one child to other. While some children learn vocabulary at the age of two, otherslearn at four or five.

However, academic learning begins at school. Teaching is a group activity and learning a personal activity. A teacher teaches a group of thirty or more. Teaching, training and other structured learning opportunities are activities that one person does to another, while learning is something we can do only to ourselves. All students cannot learn alike. It mostly depends on their knowledge, family background and surroundings. Learning skills can be acquired from different walks of life where people practise it in different stages during their existence. Workers practising handicrafts also need learning skills

With a different concept, they inherit the skill from their parents. Mere observation and dedication is essential. It is a hereditary skill. A weaver, a potter, a goldsmith, a sculptor, a carpenter and many other craftsmen rarely attend school to learn their profession. They may go to school to gain general knowledge.

Almost every action we take is the result of past learning. Yet, for some people learning still remains an activity undertaken in, or associated with an educational context. Learning is an on-going process that commences at birth and continues till death.

'Learning skills' is a term that describes the tasks involved in learning including time management, note taking, reading effectively, study skills and writing skills. The foremost thing in learning is concentration of the learner. Without this, nobody can flourish. In this context, the episode of Ekalavya in "The Mahabharat" can be seen. Ekalavya belonged to tribal community. He was interested in archery. One day he went to Dronacharya, an adept in 
archery, and requested him to impart training to him. Drona, who was then giving training intechniques of warfare to the Pandavas and the Kauravas, refusedsaying that he would teach Brahmins and Kshatriyas only. Ekalavya went away. He made the idol of Drona with mud. He used to pray to the icon daily and started practising archery. Within a short period he became dexterous in that skill. Here the concentration of Ekalavya must be appreciated. In the same way, a learner must be attentive in a classroom. He must always look at the teacher and listen tohim carefully.

Another thing is punctuality. A learner should attend classroom well before the teacher enters. If he comes late, he will miss some details or some particulars related to the topic and the attention of all students in class is diverted and disturbed. Discipline is also essential for a learner. He must always follow the instructions given by the teacher and the school management. Creative thinking and critical thinking are key factors in learning. A learner after listening to a lesson in the class must think about it and try to create some new ideas. He may discuss his opinion with the teacher and seek clarification.

Critical thinking on the other hand makes a learner distinguish between an important and an unimportant thing. Sometimes, what he learns may be wrong or insufficient. When he analyses it critically, he may find some useful additions to the subject.

Note taking definitely helps a learner to understand the subject. He can refer to the notes later for any clarification. In the text books, the matter is vast and he cannot memorise or reproduce it as it is in the examinations. If he takes notes, picking up, important and relevant points, he can remember and fare well in the examinations.

A learner should read books effectively. If necessary he must read them twice or thrice, because a teacher may not explain the subject completely in the classroom. So, the learner should read well until he acquires knowledge about it. If necessary he can refer to dictionary and other similar books. 
Learning skill is clearly demonstrated by a learner in writing tests. He should show preciseness, clarity and his knowledge of the subject. He must write only correct answers in the test. Length is not important, but accuracy is important.

Learning skills in English Language Teaching include listening skills, speaking skills, reading skills and writing skills. In order to communicate well in everyday work, these skills are vital for students and employees. So the authorities have made arrangements to impart communication skills in professional colleges and other higher education institutions. The results of academic assessment, essays, exam etc. are simply attempts to measure how much an individual has learnt. But they cannot measure the actual process of learning. There are several important things to be followed by learners to become experts in learning skills and gain efficiency.

The learning skills discussed so far confine to students pursuing studies in educational institutions. They are also called study skills or academic skills. Almost every action we take is the result of past learning. Yet, for some people learning still remains an activity undertaken in, or associated with an educational context.

But one cannot put a full stop to learning skills. It is a permanent process. Scientists and researchers even at the age of seventy or eighty continuously develop their skills and innovatethings which are useful to mankind. However it is now recognised, that learning is a continuous process that commences at birth and continues until death; it is the process through which we use our experience to deal with new situations and to develop relationships.

It is apt to recollect with a great saying by Sri Jiddu Krishnamurthy, a famous philosopher and spiritual writer and speaker. He says "There is no end to education. It is not that you read a book, pass an examination, and finish with education. The whole of life, from the moment you are born to the moment you die, is a process of learning." 
Finally, it must be observed that teaching skills followed by teachers and learning skills practised by students play a vital role in achieving the goal of education to a large extent. 


\section{References}

Aggarwal, J. C. 1995, Educational Technology, New Delhi: Vikas Publishing House.

Pathak, R. P. 2012. Teaching skills, Delhi: Dorling Kindersley, (India) pvt. Ltd, Licensees of Pearson Education in South Asia.

Pandey, K. P. 1988. Dynamics of Teaching Behaviour. Ghazibad: Amitash Prakashan.

Sampath, k. 1984. Introduction to Educational Technology, New Delhi: Sterling Publishers.

Sharma, R. A. 2005. Technological Foundation of Education, Meerut: R. Lal Book Depot.

Singh, Amrik. (eds). 1993. The Craft of Teaching. Daryaganj: Kanishka Publishers.

Skinner, B. F. 1968. The Technology of Teaching. Newyork: Appletion Century.

www.skillsyouneed.com/learning-skills.html. 